\title{
Evaluation of Papaya Varieties for Yield and Quality Parameters under Northern Dry Zone of Karnataka, India
}

\author{
G. Tulasigeri*, D.P. Prakash, B.S. Sagar and J. Beerappa
}

Department of Fruit science, Bagalkot, College of Horticulture, University of Horticultural

Sciences Bagalkot, 587-104, Karnataka, India

*Corresponding author

\section{A B S T R A C T}

\begin{tabular}{|l|}
\hline Key w or d s \\
Yield, Quality, \\
Evaluation and dry \\
zone.
\end{tabular}

\section{Introduction}

The fruit has high nutritive and medicinal value (Azad, et al., 2012) especially vitamin A (2020 IU/100g). It also possesses vitamin B, folate and pantothenic acid besides minerals like potassium and magnesium (Popenoe, 1974). It is an excellent source of beta carotene which may prevent cancer, diabetes, and heart disease (Aravind et al., 2013) and it is also utilized in the pharmaceutical and cosmetic industries (Retuta et al., 2012). The proteolytic enzyme 'papain' obtained from raw fruit is used for tenderizing meat, preparation of chewing gum, pre shrinking of wool, degumming natural silk, in cosmetics etc. India leads the world in papaya production and occupies an area about 114.97 thousand hectares, with annual production of 4912 MT and productivity of tonnes and $42.30 \mathrm{t} \mathrm{ha}^{-1}$ respectively (NHB, 2015).

States which grow papaya are Andhra Pradesh, Gujarat, Maharashtra, Karnataka, Assam, Bihar, Kerala, Orissa and West Bengal. Among them, the highest share of production $(27.40 \%)$ was occupied by Andhra Pradesh, followed by Gujarat (21\%) and Maharashtra (8.9\%) (Anon, 2015). In Karnataka, it is cultivated an area of 6.75 
thousand hectares with annual production of $471.75 \mathrm{mT}$ with productivity of $70.5 \mathrm{MT}$. The vegetative, reproductive and quality responses of crop varieties are influenced by agroclimatic conditions of a particular region. Furthermore, morphological characters have been used to characterize accessions and define the structure of varieties collection, and also important for assessing genetic diversity and correlation in varieties collection and developing crop management strategies (Burton and Devane, 1953; Bhatt, 1973). Hence, it appears, inclusion of region specific varieties of a crop plant in package of practices is much necessary. Therefore, there is need to carry out evaluation of papaya varieties for yield, physico-chemical characteristics and more net returns in all agroclimatic zones of state and country.

India having varied agro climatic conditions and there is lack of studies related to evaluation of newly developed varieties to find out suitability of such varieties to varied agroclimatic conditions. Also, just selecting a suitable variety for a particular agroclimatic region will lessen the burden of crop management by farmer to a greatest extent to get high optimum yield. Because of this evaluating different varieties of papaya suitable for different agro climatic conditions should take front seat for recommending varieties suitable for different agroclimatic regions. However, no such study has been noticed related to evaluation of papaya varieties under northern dry zone of Karnataka. Therefore, the present investigation is planned with an objective evaluation of recently released varieties from public and private institutes with respect to reproductive and quality parameters under northern dry zone of Karnataka.

\section{Materials and Methods}

Experiment conducted on "Evaluation of papaya varieties for yield and quality parameters under northern dry zone of Karnataka" was carried out during May 2015 to January 2016 at Haveli (Fruit orchard) and in fruit science lab, Bagalkot, University of Horticultural Sciences, Bagalkot, with 6 papaya varieties.

The details of the material used and the methods adopted during the course of the investigation are enumerated in this chapter. Bagalkot is located in Northern Dry Zone (Zone-3) of Karnataka State at $16^{0} 10^{1}$ North latitude, $75^{0} 42^{1}$ East longitudes and at an altitude of $542.0 \mathrm{~m}$ above the mean sea level.

\section{Location of experiment}

Bagalkot is located in Northern Dry Zone (Zone-3) of Karnataka State at $16^{0} 10^{1}$ North latitude, $75^{\circ} 42^{1}$ East longitudes and at an altitude of $542.0 \mathrm{~m}$ above the mean sea level.

Bagalkot which comes under zone-3 of region-2 among the agro climatic zone of Karnataka has benefited by both South-West and North-East Monsoons.

\section{Experimental details}

One variety was considered as a treatment and each treatment was replicated four times. There were 12 plants marked in replication of which four plants were randomly selected for recording the observations. The experiment was laid out in Randomized Complete Block Design (RCBD). The details of different treatments are mentioned below.

$\mathrm{T}_{1}$ : Red Lady, $\mathrm{T}_{2}$ : Arka Surya, $\mathrm{T}_{3}$ : Arka Prabhat, $\mathrm{T}_{4}$ : Vinayaka, $\mathrm{T}_{5}$ : Coorg Honey Dew, $\mathrm{T}_{6}$ : Amrita

After harvest fruit yield and quality parameters were recorded. Among harvested fruits, five fruits were randomly selected from each treatment for average weight of fruit. The mean value of fruit weight $(\mathrm{kg})$ was 
calculated. The mean weight of fruit was multiplied with number of fruits per plant observed at harvest and expressed in kilograms $(\mathrm{Kg})$. Length of eight fruits in each treatment was measured from proximal end to distal end and expressed in centimetre $(\mathrm{cm})$, middle, bottom and top portion of fruit was selected for measurement of diameter of fruit and measured with the help of measuring tape then average value of five fruits was worked out, single halved papaya fruits cavity diameter was measured by using thread from middle, bottom and top portion of cutted fruit then average value of five fruits was worked out and expressed in centimetre $(\mathrm{cm})$, the total soluble solids was recorded with the extracted juice using a hand refractometer at room temperature and expressed in ${ }^{\circ}$ Brix. By tasting the fruit and score was given on the basis of colour, flavour and appearance (1$10)$.

The pulp colour was recorded in ripe fruits using Royal Horticultural Society (RHS) colour chart. After cutting the fruits into two halves, the pulp thickness was measured at mid region and expressed in centimetre $(\mathrm{cm})$. The shelf -life of fruits was recorded as the days required from harvesting to optimum eating stage.

\section{Titratable acidity}

The method described by Ranganna (1979) was adopted for estimation of titratable acidity. To obtain acidity (\%), $10 \mathrm{~g}$ of homogenized pulp was taken in a $100 \mathrm{ml}$ volumetric flask and the volume was made up with distilled water to a known amount. After thirty minutes, the suspension was filtered through Whatman No. 1 filter paper and $10 \mathrm{ml}$ of filtrate was taken by pipeting and titrated against $0.1 \mathrm{~N} \mathrm{NaOH}$ by using phenolphthalein as an indicator. Appearance of colourless to pink colour denotes the end point. The reading of burette was noted.

\section{Ascorbic acid content (mg/100 g pulp)}

Titrimetric method described by Ranganna (1979) was adopted for estimation of ascorbic acid.

\section{Procedure}

Ten gram of homogenized pulp was taken and transferred to $100 \mathrm{ml}$ volumetric flask. The volume was made up with $4 \%$ oxalic acid solution. After 30 minutes, the suspension was filtered through Whatman No.1 filter paper. Before actual titration the 2, 6Dichlorophenol indophenol (Dye solution) was standardized by titrating against standard ascorbic acid solution and the dye factor was calculated. Five $\mathrm{ml}$ of the aliquot was taken from the filtrate and titrate against standardized dye solution through a burette. The titration was continued till the light pink colour persisted for 15 seconds. The ascorbic acid content was calculated adopting the following formula.

Ascorbic acid in standard $\mathrm{x}$ TV2 $\mathrm{x}$ Total sample volume

Ascorbic acid $=\longrightarrow \times 100$ Volume taken $\mathrm{x}$ TV1 x Weight of the sample

\section{Results and Discussion}

\section{Yield}

The yield in case of papaya can be measured in terms of average fruit weight, fruit yield per plant, yield per hectare, fruit length, fruit breadth, fruit diameter and cavity diameter.

Table 1, depicts maximum fruit length in the variety Vinayaka $(23.46 \mathrm{~cm})$ and minimum was recorded in variety Coorg Honey Dew $(16.27 \mathrm{~cm})$. The highest fruit length mainly due to elongated fruit shape. The variation in fruit length might be based on the fact that every genotypes has its own nature in 
development of fruits which may be varied due to various physiological phenomenon, viz. photosynthetic efficiency, rate of translocation of photosynthates from source to sink and photo-respiration that takes place in the plant body. These results are in contrast with Das (2013) and Tyagi et al., (2015) according to them the study showed that there were two fruit shapes for Red Lady 786.

As mentioned above, the fruits from pistillate flowers were oval, while an oblong shape was found in the fruits: derived from hermaphrodite flower. The fruits of Pusa Dwarf variety were oval or round shaped. This may be because Pusa Dwarf is a dioecious variety with only pistillate flowers on female plant. The fruits of local variety Madhu were also characterised with an oval shape. A major proportion of fruits in Arka Prabhath were governed with a blossom end tapered shape, while the fruits of Surya exhibited an elliptic shape.A similar finding was recorded by Chalak et al., (2016) The maximum length: breadth ratio (1.48) exhibited by cv Red Lady. It was due to its characteristic elongated fruit shape, which is also preferred for easy transport.

Among the varieties maximum fruit breath was observed in variety Red Lady $(17.23 \mathrm{~cm})$ and minimum was recorded in the variety Arka Surya $(9.04 \mathrm{~cm})$. The variation in fruit breadth and pulp thickness might be based on the fact that every genotypes has its own nature in development of fruits which may be varied due to various physiological phenomenon, viz. photosynthetic efficiency, rate of translocation of photosynthates from source to sink and photo-respiration that takes place in the plant body. These results are in contrast with Das (2013), Das and Dinesh (2014) and Chalak et al., (2016).

Vinayaka recorded maximum fruit diameter $(12.69 \mathrm{~cm})$ and minimum was recorded in the variety Arka Surya $(8.02 \mathrm{~cm})$. The variation in fruit diameter might be based on the fact that every genotype has its own nature in development of fruits which may be varied due to various physiological phenomenon, viz. photosynthetic efficiency, and rate of translocation of photosynthates from source to sink and photo-respiration that takes place in the plant body. These results are in contrast with Goenaga et al., (2001) and Tyagi et al., (2015) according to them the study showed that there were two fruit shapes for Red Lady 786. As mentioned above, the fruits from pistillate flowers were oval, while an oblong shape was found in the fruits: derived from hermaphrodite flower. The fruits of Pusa Dwarf variety were oval or round shaped. This may be because Pusa Dwarf is a dioecious variety with only pistillate flowers on female plant. The fruits of local variety Madhu were also characterised with an oval shape. A major proportion of fruits in Arka Prabhath were governed with a blossom end tapered shape, while the fruits of Surya exhibited an elliptic shape.

Maximum cavity diameter was recorded in the Arka Prabhat $(7.52 \mathrm{~cm})$ and minimum was found in the Arka Surya $(6.22 \mathrm{~cm})$. These results are in contrast with Tyagi et al., (2015) the variations among the varieties may be attributed to their genetic constitution. The differential ability of photosynthetic rate per unit leaf area per unit time can also be responsible for the varied fruit weight.

Table 2, depicts the variety Vinayaka recorded the maximum average fruit weight $(2.36 \mathrm{~kg})$ and minimum was found in variety Arka Surya $(0.74 \mathrm{~g})$. This might be due to the genetical characters. These results are in accordance with the findings of Chalak et al., (2016), Kumar et al., (2015), Meena et al., (2012) and Jana et al., (2010). Anh et al., (2011) recorded that measurements showed that the depth of flesh (DepF) of the 
hermaphrodite plants was deeper than that of the pistillate plants. The Depth of flesh of the pistillate plants ranged from $2.00 \mathrm{~cm}$ (LCH12) to $2.50 \mathrm{~cm}$ (TQH), while that of the hermaphrodite plants varied from $2.17 \mathrm{~cm}$ (LCH12) to $2.97 \mathrm{~cm}$ (DLD02). In addition, variety DLD02 had the highest weight of fruit (WtFr), $1.84 \mathrm{~kg} /$ fruit, while the Weight of other varieties ranged from $0.61 \mathrm{~kg} /$ fruit to $1.64 \mathrm{~kg} /$ fruit.

Among the varieties, maximum yield per plant was recorded in the variety Vinayaka $(53.30 \mathrm{~kg})$ and minimum was recorded in Arka Surya $(13.30 \mathrm{~kg})$. These results are in contrast with Chalak et al., (2016) recorded maximum yield per plant was recorded in the variety Pusa Giant $(66.1 \mathrm{~kg})$. These results are in contrast with Meena et al., (2012) recorded yield per plant was recorded highest in variety Pusa Nanha this was mainly due to The variations in yield attributes of papaya might be due to various physiological phenomenon, viz. photosynthetic efficiency, rate of translocation of photosynthates from source to sink and photo-respiration that took place in the plant body and different genetic constitution of varieties, which are responsible for expression of genetic characters under a particular set of environment. Moreover, yield performance of any variety is considered as a cumulative effect of yield attributes and the hybrid Surya could not come upto fruit bearing stage due to unfavourable climatic conditions. Similar findings were found in Tyagi et al., (2015), Anh et al., (2011). Fruit yield plant ${ }^{-1}$ had significant positive both association with plant height at flowering, petiole length, number of leaves at flowering, fruit length, fruit girth, central cavity, pulp thickness, TSS and number of fruits plant ${ }^{-1}$ both at genotypic and phenotypic level respectively.

Vinayaka recorded the maximum yield per hectare (164.46 t/ha) and minimum was recorded in the variety Arka Surya (164.46 t/ha).Similar findings were found in Pastors et al., (2010) maximum yield per hectare was recorded in variety Sunset (158627 kg / ha).These results are in contrast with Meena et al., (2012) recorded yield per hectare was recorded highest in variety Pusa Nanha this was mainly due to The variations in yield attributes of papaya might be due to various physiological phenomenon, viz. photosynthetic efficiency, rate of translocation of photosynthates from source to sink and photo-respiration that took place in the plant body and different genetic constitution of varieties, which are responsible for expression of genetic characters under a particular set of environment. Moreover, yield performance of any variety is considered as a cumulative effect of yield attributes and the hybrid Surya could not come upto fruit bearing stage due to unfavourable climatic conditions of north Gujarat. Fruit yield plant $^{-1}$ had significant positive both association with plant height at flowering, petiole length, number of leaves at flowering, fruit length, fruit girth, central cavity, pulp thickness, TSS and number of fruits plant ${ }^{-1}$ both at genotypic and phenotypic level respectively Kumar et al., (2015).

\section{Quality parameters}

Quality parameters like TSS, titratable acidity, ascorbic acid content, pulp thickness, shelf life and sensory evaluation were significantly differ among the treatments. The progenies in both the varieties Arka Surya and Arka Prabhath, which are found to have higher fruit weight, higher TSS or pulp thickness, were observed not to be the same progenies (e.g. the progeny P9 of Arka Prabhath showed higher pulp thickness but lower TSS). In Arka Surya and Arka Prabhath under standably the seed yield per fruit among the progenies varied because of the sex types. 
Table.1 Performance of papaya genotypes in respect to fruit parameters

\begin{tabular}{|c|c|c|c|}
\hline Treatments & $\begin{array}{c}\text { Average fruit } \\
\text { weight(kg) }\end{array}$ & $\begin{array}{c}\text { Yield per } \\
\text { plant(kg) }\end{array}$ & $\begin{array}{c}\text { Yield per } \\
\text { hectare(t) }\end{array}$ \\
\hline T1- Red Lady & 2.10 & 48.40 & 149.36 \\
\hline T2- Arka Surya & 0.74 & 13.30 & 41.04 \\
\hline T3- Arka Prabhat & 1.34 & 23.79 & 73.41 \\
\hline T4- Vinayaka & 2.36 & 53.30 & 164.46 \\
\hline T5- Coorg Honey Dew & 1.54 & 20.46 & 63.14 \\
\hline T6- Amrita & 0.87 & 22.43 & 69.21 \\
\hline S.Em. \pm & 0.10 & 1.27 & 2.81 \\
\hline CD @ 5\% & 0.31 & 3.83 & 8.49 \\
\hline
\end{tabular}

Table.2 Performance of papaya genotypes in respect to yield parameters

\begin{tabular}{|c|c|c|c|c|}
\hline Treatments & $\begin{array}{c}\text { Fruit length } \\
(\mathbf{c m})\end{array}$ & $\begin{array}{c}\text { Fruit breadth } \\
(\mathbf{c m})\end{array}$ & $\begin{array}{c}\text { Fruit diameter } \\
(\mathbf{c m})\end{array}$ & $\begin{array}{c}\text { Cavity diameter } \\
(\mathbf{c m})\end{array}$ \\
\hline T1- Red Lady & 20.22 & 17.23 & 12.42 & 6.51 \\
\hline T2- Arka Surya & 16.48 & 9.04 & 8.02 & 6.22 \\
\hline T3- ArkaPrabhat & 21.24 & 13.24 & 11.61 & 7.52 \\
\hline T4- Vinayaka & 23.46 & 15.13 & 12.69 & 6.41 \\
\hline T5- Coorg Honey Dew & 16.27 & 13.59 & 10.05 & 7.12 \\
\hline T6- Amrita & 22.32 & 11.46 & 8.19 & 6.32 \\
\hline S.Em. \pm & 0.54 & 0.34 & 0.30 & 0.23 \\
\hline CD $(0.05)$ & 1.62 & 1.01 & 0.91 & 0.71 \\
\hline
\end{tabular}

Table.3 Performance of papaya genotypes in respect of quality parameters

\begin{tabular}{|l|c|c|c|c|c|}
\hline \multirow{2}{*}{ Treatments } & \multicolumn{5}{|c|}{ Quality parameters } \\
\cline { 2 - 6 } & $\begin{array}{c}\text { TSS } \\
\text { ('Bricks) }\end{array}$ & $\begin{array}{c}\text { Acidity } \\
(\mathbf{\%})\end{array}$ & $\begin{array}{c}\text { Ascorbic acid } \\
(\mathbf{m g} / \mathbf{1 0 0 g} \\
\mathbf{p u l p})\end{array}$ & $\begin{array}{c}\text { Shelf life } \\
\text { (days) }\end{array}$ & $\begin{array}{c}\text { Pulp } \\
\text { thickness } \\
(\mathbf{c m})\end{array}$ \\
\hline T1- Red Lady & 9.60 & 0.16 & 50.21 & 7.06 & 2.93 \\
\hline T2- Arka Surya & 7.32 & 0.13 & 60.86 & 5.46 & 2.78 \\
\hline T3- ArkaPrabhat & 7.36 & 0.11 & 59.12 & 8.11 & 2.96 \\
\hline T4- Vinayaka & 9.32 & 0.14 & 51.78 & 5.20 & 3.20 \\
\hline T5- Coorg Honey Dew & 7.65 & 0.13 & 55.04 & 4.58 & 2.55 \\
\hline T6- Amrita & 8.78 & 0.13 & 55.18 & 4.15 & 2.55 \\
\hline S.Em. \pm & 0.19 & 0.01 & 1.18 & 0.37 & 0.09 \\
\hline CD @ 5\% & 0.59 & 0.04 & 3.57 & 1.13 & 0.26 \\
\hline
\end{tabular}


Table.4 Performance of papaya genotypes in respect organoleptic evaluation

\begin{tabular}{|c|c|c|c|c|}
\hline \multirow{2}{*}{ Treatments } & \multicolumn{4}{|c|}{ Sensory evaluation } \\
\cline { 2 - 5 } & $\begin{array}{c}\text { Fruit colour and } \\
\text { appearance }\end{array}$ & $\begin{array}{c}\text { Pulp } \\
\text { Colour }\end{array}$ & $\begin{array}{c}\text { Taste and } \\
\text { flavour }\end{array}$ & Over all acceptability \\
\hline T1- Red Lady & 7.82 & 8.68 & 8.31 & 8.29 \\
\hline T2- Arka Surya & 7.65 & 7.87 & 8.14 & 7.95 \\
\hline T3- ArkaPrabhat & 6.10 & 5.85 & 5.75 & 5.95 \\
\hline T4- Vinayaka & 7.71 & 8.55 & 8.15 & 8.12 \\
\hline T5- Coorg Honey Dew & 4.50 & 4.75 & 5.25 & 5.00 \\
\hline T6- Amrita & 4.31 & 4.35 & 4.55 & 4.41 \\
\hline
\end{tabular}

Table 3, depicts the maximum TSS in the variety Red Lady ( $9.60^{\circ}$ brix) and minimum was recorded in Arka Surya $\left(7.32^{\circ}\right.$ brix). These results was negatively correlated with ascorbic acid and positively correlated with titratable acidity. Similar findings was recorded by Tyagi et al., (2015) which might be attributed to its high photosynthetic efficiency and fast rate of diversion of sugars from source (leaf) to sink (fruit), in comparison to other varieties. Kwame (4) reported that sugar forms the main component of soluble solids in ripe papaya.

Therefore, the high amount of total soluble solids in Red Lady 786 may be attributed to its high sugar content. In contrast, the variety Madhu recorded the lowest amount of total soluble solids $\left(8.06^{\circ}\right.$ Brix) and total sugars $(3 \%)$. These results are in contrast Jana et al., (2010) and Chalak et al., (2016). According to Meena et al., (2012) the result was mainly due to the total soluble solids were found in Pusa Delicious followed by Pant Papaya-1, whereas minimum TSS was found in Pusa Nanha. The variation in TSS in varieties might be due to their genetic makeup and its own nature of variety which govern the chemical composition of the fruits.

Arka Prabhat recorded the minimum acidity $(0.11 \%)$ and maximum found in variety Red Lady $(0.16 \%)$. This was mainly due to genetical character of variety and positive correlation with the total soluble solids. Similar finding was recorded by Das and Dinesh (2014) maximum titratable acidity was recorded in Waimonnalo and lowest in case of hybrids $\mathrm{H}-39, \mathrm{H}-57$ and CO-4.These results are in contrast with Das (2013) and Devi (2010).

Among the varieties highest ascorbic acid was recorded in the variety Arka Surya (60.86 mg) and minimum was recorded in the variety Red Lady $(50.21 \mathrm{mg})$. These results was accordance with Das and Dinesh (2014) highest ascorbic acid was recorded in the variety H-39 and Red Gold and lowest was recorded in the variety Waimanalo.

The longest shelf life was recorded in the variety Arka Prabhat (8.11 days) and shortest was found in Amrita variety (4.15 days). The shelf life of variety is long mainly due to shininess of fruit.

Among the varieties maximum pulp thickness was recorded in the variety Vinayaka $(3.20 \mathrm{~cm})$ and minimum was recorded in the varieties $(2.55 \mathrm{~cm})$ Amrita and Coorg Honey Dew. Similar findings was recorded by Meena et al., (2012) according them The variation in pulp thickness might be based on the fact that every genotypes has its own nature in development of fruits which may be varied due to various physiological phenomenon, viz. photosynthetic efficiency, rate of translocation of photosynthates from source to sink and photorespiration that takes place in the plant body. These results are in contrast with Jana et al., (2010), Chalak et al., (2016) and Das and Dinesh (2014). 
Among the varieties maximum score for sensory evaluation was recorded in the variety Red Lady (8.29) and minimum score was recorded in the variety lowest score (4.41) was given to the genotype Amrita(table 4). These results are in contrast with Meenaet al., (2012).

\section{References}

Anh, N. T., Trang, P. N., Hong, N. T. B. and Hoan, N. G., 2011, Evaluating agronomic characteristics of twelve local papaya (Carica papaya L.) varieties in Viet Nam. Bull. Inst. Trop. Agr., 34: 15-22.

Anon, 2015, Indian Horticulture Database2015.http: //www. Nhb. gov.in.

Anon, 2015, VNR Private Seed Company2015.http: //www.VNR.in.

Aravind, G., Bhowmik, D., Duraival, S. and Harish, G., 2013, Traditional and Medicinal uses of Carica papaya. Journal of Medicinal Plant Studies, 1 (1): 7-15.

Azad, M. A. K., Rabbani, M. G. and Amin, L., 2012, Plant regeneration and somatic embryogenesis from immature embryos derived through interspecific hybridization among Carica species. International Journals of Molecular Sciences, 13: 1706517076.

Bhatt, G. M., 1973, significant path coefficient analysis in determining the nature of characters association. Euphytica. 22 (2): 338-343.

Burton, G. W., and Devane, E. H., 1953, Estimated heritability in tall fescue (Fescue arundinacea) from replicated clonal material. Agron. J., 45:478-480.

Chalak, S. U., Kamble, A. B. and Bhalekar, S. G., 2016, Evaluation of different papaya cultivars for yield, quality and papaya ring spot disease under pune conditions. J Krishi Vigyan., 5 (1): 60-63.

Das, S. C., 2013, Studies on papaya cultivation and evaluation of different varieties and hybrids in Tripura. Asian J. Hort.8 (2):470474.

Das, S. C., and Dinesh, M. R., 2014, Studies on fruit set and germination in some papaya cultivars. Acta Hort.1022: 87-90.

Devi, P. S., Thangam, M., Ladaniya, M. S. and Korikanthimath, V. S., 2011, Evaluation of local banana cultivars under coconut shade in Goa. J. Biol. Chem. Res., 28: 63-76.

Goenaga, R., Irizarry, H. and Amadora, R., 2001, Yield and fruit quality of papaya fruits grown at two locations in Puerto and Rico. J. Agric. Univ P. R., 85 (3-4): 127-134.

Jana, B. R., Rai, M., Nath, V. and Das, B., 2010, Promising papaya (Carica papaya L.) varieties for Subtropical Plateau Region of Eastern India. Acta Hort. 851: 131-136.

Kumar, M., Prasad, Y., Kumar, M., Prakash, S. and Kumar, S., 2015, Evaluation of genetic variability, genetic advance, heritability and character association for yield and its contributing traits in papaya (Carica papaya L.). Society Plant Research.28 (2): 99-102

Meena, B.S., Varma, L.R. and Mehta, R.S., 2012, Evaluation of papaya varieties under North Gujarat conditions.Indian J. Hort. 69 (1): 114-116.

Popenoe, W., 1974, Manual of Tropical and Sub tropical Fruits, Hafner Press, 225-269

Ranganna, S., 1979, Handbook of analysis and their quality control for fruits and vegetable products. $2^{\text {nd }}$ Edn. Tata McGraw-Hill publishing co. Ltd. New Delhi, India, pp. 982.

Retuta, 2012, Biochemical characteristics of papaya, Processing of the XV Eucarpia meeting on genetics and breeding of papaya., 2-4 september2013, torino-Italy.

Tyagi, M., Singh, H. and Jawandha, S. K., 2015, Performance of papaya cultivars grown under protected conditions. Indian J. Hort., 72 (3): 334-337.

\section{How to cite this article:}

Tulasigeri, G., D.P. Prakash, B.S. Sagar and Beerappa, J. 2017. Evaluation of Papaya Varieties for Yield and Quality Parameters under Northern Dry Zone of Karnataka, India. Int.J.Curr.Microbiol.App.Sci. 6(10): 2516-2523. doi: https://doi.org/10.20546/ijcmas.2017.610.295 